\title{
DESCRIPTION OF DNA ANALYSIS TECHNIQUES AND THEIR APPLICATION IN OAT (Avena L.) GENOME RESEARCH
}

\author{
Sylwia Okoń, Krzysztof Kowalczyk \\ Institute of Plant Genetics, Breeding and Biotechnology, University of Life Sciences in Lublin, \\ Akademicka 13, 20-950 Lublin, Poland \\ e-mail: sylwia.okon@up.lublin.pl
}

Received: 06.10.2011

\begin{abstract}
DNA markers are used not only to estimate genetic similarity and distance but also to select and identify desirable forms, to assess the adjustment of breeding material, to confirm crossbreeding efficiency, to determine seed purity, and to identify the genes which determine important functional traits. In the case of oat, DNA markers were used to construct and increase the density of genetic maps both in hexaploid and diploid species. The development of markers for some important traits provides a fast selection of genotypes containing dwarf genes as well as the resistance genes to crown rust and powdery mildew. Numerous analyses of genetic similarity between different species belonging to the genus Avena which are currently carried out may contribute to explaining the process of evolution within this genus and may also explain the development of particular species of oat.
\end{abstract}

Key words: Avena L., DNA analysis, molecular markers

\section{Techniques of DNA analysis}

DNA markers are more and more commonly used in plant breeding; they are used not only to estimate genetic similarity and distance but also to select and identify desirable forms, to assess the adjustment of breeding material, to confirm crossbreeding efficiency, to determine seed purity, and to identify the genes for important functional traits (W olk o and $\mathrm{Kruszka}$, 1997). DNA markers are fragments of deoxyribonucleic acid, obtained as strands on gels or membranes, which are the final products of enzymatic reactions or hybridisation. The description of genotypes by means of this type of markers consists in the amplification of one or several DNA fragments from a given sample. Fragments which have a specific length and nucleotide sequence may be treated as a hereditary marker, typical of the given genotype (W o l k o et al. 1999). DNA markers provide the possibility of analysing the diversity of organisms, irrespective of the stage of their development and the effect of environmental factors. Moreover, they guarantee a high repeatability of results and easiness of application, which makes them very useful (S z t u b a - S oli í s ka, 2005).

The oldest method of DNA analysis is RFLP - Restriction Fragment Length Polymorphism (B o ts te in et al. 1980). This technique consists in digesting genomic DNA using one or two restriction enzymes and separation on agarose gel; then, the obtained fragments are placed on nylon filters and hybridised with a molecular probe. The drawbacks of RFLP technique include, first of all, its labour intensity and the necessity to have a large amount of well-purified DNA at one's disposal. RFLP markers are believed to be very stable and highly repeatable and that is why they are widely used for mapping of plant genomes ( $\mathrm{De}$ vo s et al. 1993; O 'D o n o u g hue et al. 1995) and for selection of breeding material (Helentiaris, 1985).

The development of PCR - Polymerase Chain Reaction, was a turning point in the analysis of genetic variability at the DNA level (M u 11 i s , 1990). Most of DNA analysis techniques are based on the PCR method (W olko and Kruszka, 1997). It is relatively simple and enables a fast and precise in vitro replication of template DNA or cDNA. Techniques based on PCR are commonly used in plant genetics and they also have been used to identify agricultural cultivars $(\mathrm{Hu}$ and Q u iros , 1991) and important functional traits ( $\mathrm{H} \mathrm{a}$ le y et al. 1993), to define the origin of hybrid materials (W e $1 \mathrm{~s} \mathrm{~h}$ et al. 1991), to study the species relationship (Wilke et al. 1993), and for gene mapping (Weining and Langridge, 1991).

Different modifications of the PCR method are commonly used in plant genetics and breeding. The 
simplest technique that provides fast detection of differences in DNA sequence in the whole genome is RAPD - Randomly Amplified Polymorphic DNA, described by Wiliams et al. (1990). Amplification is conducted in the presence of one primer consisting of 9-11 nucleotides and a randomly selected sequence containing $50-80 \%$ of $\mathrm{G}$ and $\mathrm{C}$ bases. Primers join the studied DNA in many places, initiating amplification of several different fragments. Amplified fragments are separated on agarose gel and dyed with ethidium bromide. Because the number of different sequences of primers is virtually unlimited, the RAPD method has been used to identify markers linked to the genes conditioning important functional traits ( $\mathrm{P} \mathrm{e} \mathrm{n} \mathrm{n} \mathrm{e} \mathrm{r} \mathrm{et} \mathrm{al.} \mathrm{1993;} \mathrm{Z} \mathrm{o} \mathrm{-}$ r z a t to et al. 2010), to study polymorphism (M a r i 1 $1 \mathrm{a}$ and Scoles, 1996; A bdella oui et al. 2010), to conduct phylogenetic analyses (Gonzalez and Ferrer, 1993; Goryunova et al. 2010), to identify hybrids (H a rada et al. 1993), and to establish the identity of breeding material. One disadvantage of this method is its high sensitivity to even small changes in conditions of reaction (D e v o s and G a le, 1992).

Another technique commonly used to analyse cereal DNA is SSR - Simple Sequence Repeat, i.e. a microsatellite polymorphism of short tandem repeats. The technique is based on analysis of microsatellite DNA sequences consisting of a repeatable motif of 1-4 nucleotides. Repeatable sequences are regularly distributed on all chromosomes and demonstrate high polymorphism with respect to length, which is conditioned by a different number of repetitions of the basic sequence (S z t u b a - S o li ń s k a, 2005). The advantages of SSR markers include high polymorphism and a codominant hereditary system, which provide differentiation of closely related specimens. Consequently, SSR markers are used for gene mapping ( $\mathrm{Li}$ et al. 2009), identifying cultivars (M o r i y a et al. 2011), determining the degree of polymorphism ( $\mathrm{Li}$ et al. 2000), and as markers of functional traits ( $\mathrm{Y} \mathrm{u}$ et al. 2011). In spite of their great potential, the use of SSR markers is limited because of a high cost of their development (W o $1 \mathrm{k}$ o et al.1999).

Another technique used more and more often in research on cereal is ISSR - Inter Simple Sequence Repeat ( $\mathrm{Zi} \mathrm{e} \mathrm{t} \mathrm{k} \mathrm{i} \mathrm{e} \mathrm{w} \mathrm{i} \mathrm{c} \mathrm{z} \mathrm{et} \mathrm{al.} \mathrm{1994).} \mathrm{This} \mathrm{method}$ provides identification of polymorphism of DNA areas between microsatellite sequences. ISSR technique combines the advantages of the SSR method with universality of RAPD technique. ISSR markers demonstrate high repeatability of $92-95 \%$, which results from the fact that long starters including 16-25 nucleotides are used (Prade e p R e d y et al. 2002). In addition its repeatability, ISSR technique is relatively simple (B ednarek and Chwedorzewska, 2001). The markers are used to assess genetic relationships
(Fernande z et al. 2002), to carry out phylogenetic analyses (Qian 2001; B a o et al. 2006), and to identify important functional traits (A m miraju et al. 2001).

Mixed markers use both the properties of restriction enzymes and activity of DNA polymerase (B e d narek and Chwedorzewska, 2001). AFLP Amplified Fragment Length Polymorphism (V o s et al. 1995), is one example. This technique consists in digestion of genome DNA by means of two restriction enzymes and attaching adaptors to cutting places. As a result of pre-amplification with non-selective starters, only some fragments of DNA are strengthened; these fragments will constitute a template in selective amplification conducted in the presence of marked starters extended by 2-3 differentiating nucleotides ( $\mathrm{V}$ o s et al. 1995). DNA fragments may be identified electrophoretically on polyacrylamide gel. The advantages of AFLP include high efficiency of polymorphic identification of markers, a relatively low cost of research and the possibility to identify codominant markers (B e d narek and Chwedorzewska, 2001). Consequently, AFLP technique is used to identify markers linked to resistance to diseases ( $\mathrm{S} \mathrm{h}$ a r m a, 1996; Li et al. 2010), to establish relationships ( $\mathrm{Y}$ u et al. 2007; A k kale et al. 2010) and for gene mapping ( $\mathrm{Zh} \mathrm{u}$ et al. 1998).

Markers which provide identification of desirable genes in a simple way and, consequently, enable a fast and effective selection of interesting genotypes play the most important part in plant breeding for practical purposes. Specific PCR consists in duplicating a precisely defined genome fragment by two starters (C o le et al. 1991). Specific markers include STS (Sequence Target Site) markers (W e e d e n et al. 1994) and SCAR (Sequence Characterised Amplified Region) markers (P a a n and M i che l m or e, 1993). STS markers are obtained by conversion of RFLP markers. Their development requires knowledge about the sequence of a DNA fragment; however, they make it possible to obtain a single specific PCR product. The STS marker system is mainly used to increase the density of genetic maps (Khlestkin a et al. 2002; L o a r c e et al. 2009) and to look for a linkage of functional traits (W a n g et al. 2008; Chen et al. 2010). SCAR markers are obtained by conversion of RAPD markers. The procedure for development of SCAR markers is quite complex and consists in cutting out a strand of RAPD from gel, isolation of DNA, cloning of a fragment and determining its sequence. On the basis of the sequence, specific starters which include 20-24 nucleotides are designed. These starters generate one product whose length corresponds to the initial RAPD fragment (Wolko and Kruszka, 1997). Amplification of DNA by means of SCAR markers 
is definitely more specific and leads to a significant improvement in repeatability of PCR reaction ( $\mathrm{N}$ a i r et al. 1996). SCAR markers enable a fast and reliable selection of genotypes ( $\mathrm{Uhr}$ in et al. 2008; Li et al. 2010).

Markers specific to important genes are usually developed using the BSA method (M i c h e $1 \mathrm{~m}$ or e et al. 1991). This method provides fast identification of the marker linked to the gene or region in the genome. It consists in analysing two contrast DNA pools obtained from segregating a population from a single crossing. Each pool contains DNA from plants which are identical as far as the studied property is concerned but probably different regarding other traits. The pools, however, differ from one another as far as the studied trait is concerned. The pools prepared in this way are then analysed with regard to identification of the markers linked to the gene which differentiates them, by looking for differentiating strands ( $\mathrm{Mich} \mathrm{el} \mathrm{mo-}$ re et al. 1991).

Besides molecular techniques which use electrophoretic separations, hybridisation methods in combination with the technology of microarrays, which provide analysis of a much larger number of molecular markers at the same time, are becoming more and more significant. Diversity Arrays Technology (DArT) (J a c c o u n d et al. 2001) belongs to this group. DArT markers are dominant, random and, just like RAPD and ISSR, they do not require knowledge about the analysed DNA sequence. Polymorphisms of individual nucleotides, insertion-deletion changes, repeated sequences or changes in DNA methylation are the source of polymorphism of DArT markers. One advantage of DArT technology is the possibility of obtaining a large number of markers in a single experiment (K i l i a n et al. 2005).

\section{Oat mapping}

DNA markers are used for constructing genetic maps of different cereal species (H e u n et al. 1991; M e s s m e r et al. 1999; R a m s a y et al. 2000). Mapping populations obtained as a result of inter-cultivar or inter-species crossing of two different homozygous parent forms are particularly useful in the process of creating these maps. On the basis of RFLP, O ' D o noughue et al. (1995) created the first map of hexaploid oat. The authors used a mapping population consisting of 71 plants of a recombinant inbred line obtained as a result of crossing of two cultivars ' $\mathrm{Ka}$ nota' (A. byzantina) and 'Ogle' (A. sativa). The authors obtained 38 linkage groups and marked 561 loci on them. Using other marker systems, e.g. AFLP or RAPD, made it possible to increase the density of the genetic map and to reduce the number of linkage groups. J in et al. (2000) reduced their number to 34 and increased the density of the genetic map of 'Kanota'
× 'Ogle' by placing 263 AFLP markers on in. Moreover, these authors obtained another mapping population by crossing Clintland64 line with IL86-5698 line. They placed 265 AFLP markers on it; 97 of them were shared by both populations and many of them occurred in a similar order. Using also RFLP, Portyanko et al. (2001) presented a map created on the basis of 136 plants of recombinant inbred lines, obtained as a result of crossbreeding of the cultivar 'Ogle' ( $A$. sativa) with TAM O-301 line. In 34 linkage groups, the authors marked a total of 426 loci. To increase the density of the 'Kanota' x 'Ogle' map, DArT markers were also used (T i n k e r et al. 2009). These authors added 1010 new DArT markers to the genetic map of oat.

\section{Identification of markers linked to important functional traits}

Identification of genes determining important functional traits by molecular markers provides a fast and reliable selection of desirable genotypes. Consequently, looking for markers linked to different agronomic traits plays an important role in cultivation breeding. The development of specific molecular markers which constitute a fast and reliable method of identification of forms containing specific genes speeds up considerably the selection of genotypes with better agronomic properties. So far, only several molecular markers that provide a fast selection of forms containing specific genes have been identified in oat.

W i g h t et al. (2003) developed RFLP markers for Pc38, Pc39 and Pc48 resistance genes to crown rust. These authors used three populations obtained by crossbreeding of the following isogenic lines: 'Pendek-39' ' 'Pendek-48', 'Pendek-48' $\times$ Pendek-38' and 'OT328' $\times$ 'Dumont'. They found six markers linked to the $P c 48$ gene in a 'Pendek-39' $\times$ 'Pendek-48' population and three markers for the $P c 39$ gene in a 'Pendek-48' $\times$ Pendek-38' population; however, none of the obtained markers cosegregated with the $P c 39$ gene. These authors also identified 9 markers for the $P c 38$ gene in a 'Pendek-48' $\times$ Pendek-38' population, eight of which were located less than $2 \mathrm{cM}$ from this gene.

Restriction fragment lenght polymorphism was also used to look for markers linked to dwarf genes in oat (Milach et al. 1997). Using BSA - Bulked Segregant Analysis, the authors identified RFLP markers for the $D w 6$ and $D w 8$ genes. On the basis of further research, the authors showed that the obtained markers were located $3.3 \mathrm{cM}$ from the $D w 6$ gene, $4.3 \mathrm{cM}$ from the $D w 7$ gene and $4.9 \mathrm{cM}$ from the $D w 8$ gene. Moreover, the authors placed the obtained RFLP markers to linkage groups of the 'Kanota' $\times$ 'Ogle' genetic map (O' D o n o u g hu e et al. 1995).

Fennimore et al. (1999) looked for RAPD markers linked to QTL regulating long seed dormancy in wild oat species. Using the BSA method, the authors 
identified three RAPD markers which enabled differentiation of the studied plant pools. Further analyses showed that only two among the identified markers were linked to the analysed trait. Penner et al. (1993) made an attempt to identify RAPD markers linked to the $P g 3$ resistance gene to stem rust in common oat. The authors obtained two markers linked to the analysed gene; they also showed that the Copr-2 marker was totally linked to the $P g 3$ locus.

Chong et al. (2004) described a specific SCAR marker for the $P c 94$ resistance gene to crown rust. They used AFLP technique to look for a marker linked to the studied gene and then converted the obtained marker to a specific SCAR marker. Orr and Molnar (2008) identified three SCAR markers and one CAPS marker linked to the content of $\beta$-glucan; they also showed that some of these markers were linked to the genes conditioning high fat content.

McCartney et al. (2011) looked for markers linked to the resistance gene to crown rust, $P c 91$. The authors identified 44 DArT markers linked to the analysed gene and converted them into specific SCAR markers. Analysis of the developed SCAR primers showed that only five out of the obtained markers were linked to the $P c 91$ gene.

\section{Analysis of genetic similarity}

Assessment of genetic diversity plays an important role in the description of breeding lines, cultivars, and species; it is also very important for breeding programs and for selection of components for crossbreeding (Gupta et al. 2010).

Because of amplification of many fragments of DNA located in the whole genome, RAPD technique was used many times to study polymorphism in species of the genus Avena. On the basis of polymorphism of RAPD markers, P a c z o s - G r z ę d a et al. (2007b) assessed genetic similarity of 12 forms of Avena sterilis from Isreal, Syria, and Lebanon. The authors showed that the forms which came from Israel demonstrated the largest genetic similarity; these forms were closely located on the obtained dendrogram. Similarly, analysing forms of A. sterilis of different origin, Z h o u et al. (1999) observed that most forms which came from Israel clustered together and demonstrated a significant genetic similarity. Moreover, the authors showed that the forms which came from Iran, Iraq, and Turkey differed from the others and clustered with the cultivars A. sativa and A. byzantina, which may suggest their participation in evolution of agricultural species.

Using RAPD markers, $\mathrm{Chrząstek}$ et al. (2004) identified genetic similarity between species belonging to the genus Avena characterised by a different degree of ploidality. The authors selected 36 RAPD primers generating stable strand patterns.
These starters generated 251 polymorphic products $(88.7 \%)$. The assessed mean inter-species similarity was $43 \%$ and A. sativa proved to be the most similar species to all the others, whereas $A$. nuda - the most different one. The obtained dendrogram contained species of the same genomes. Using RAPD and, AFLP D ros s o u et al. (2004) studied genetic similarity of species belonging to the genus Avena, characterised by a different degree of ploidality. On the basis of the conducted analysis, the authors showed that both methods used were suitable for identification of polymorphism in the genus Avena. Moreover, the authors did not observe significant differences between the obtained dendrograms; the results obtained on the basis of RAPD and AFLP markers were highly correlated.

P a c z o s-Grzęda (2007a) identified polymorphism of 12 Polish cultivars of A. sativa on the basis of RAPD and ISSR markers. Both techniques provide identification of the studied cultivars; however, ISSR technique proved to be much more efficient because it identified a much higher level of polymorphism. De Suoza et al. (2005) assessed genetic diversity in 30 families of $A$. sativa mutants of $\mathrm{M}_{3}$ generation using 14 ISSR markers. Moreover, they made an attempt to assign molecular markers to the region connected with tolerance to the toxic effect of organic acids. As a result, the authors obtained three ISSR markers enabling identification of the region responsible for tolerance and three markers connected with sensitivity to the toxic effect of organic acids.

Paczos-Grzęda et al. (2009) used REMAP and ISSR markers to estimate interspecific genetic similarity of 12 Polish and foreign ecotypes of A. fatua. The authors found that clustering did not conform to the geographical origin of the studied genotypes. Moreover, ecotypes collected in Poland showed lower diversity than the forms which came from the other countries. The results of the experiments demonstrated significant interspecific similarity of Avena fatua.

G off re d a et al. (1992) used RFLP markers to assess genetic similarity within wild Avena sterilis species. Using 43 polymorphic probes, these authors analysed 173 genotypes which came from nine African and Asian countries. They demonstrated that genetic diversity, which is a measure of genetic distance, was the largest among the forms coming from Iran; additionally, the genetic distance coincided with geographic origin of the studied genotypes.

Polymorphism of microsatellite markers was used to estimate genetic similarity of different Avena species. Li et al. (2000) were the first to make an attempt to mark new microsatellite primers for oat. The authors designed primers flanking repeatable sequences after a prior search of the genome library of oat and sequencing DNA clones. Apart from that, they used 
54 pairs of starters designed earlier for barley to assess the diversity of 12 species of the genus Avena and 20 cultivars of $A$. sativa. They demonstrated that $62 \%$ of the developed pairs of starters showed inter-genus polymorphism and only $36 \%$ showed diversity between cultivars. The authors found that in the case of primers designed for barley only $26 \%$ of them participated in amplification of polymorphic products.

P a c z o s - Grzęd a et al. (2007c) used 55 pairs of SSR primers designed for wheat to estimate genetic similarity of hexaploid species belonging to the genus Avena. Twelve (22\%) out of the tested markers amplified polymorphic patterns of strands. The authors demonstrated that eleven selected markers could be used to assess diversity within $A$. sterilis and seven to assess diversity within A. fatua. Nine markers identified polymorphism within A. sativa cultivars.

By means of 77 polymorphic products identified by 8 selected AFLP primers, A chleitner et al. (2008) identified genetic diversity of 114 cultivars of Avena sativa which came from different parts of the world. The authors found that genotypes of common geographic origin were located together on the obtained dendrograms. Moreover, these authors showed that cultivars obtained in breeding programs in Europe were less diversified than those obtained in the countries of South and North America.

$\mathrm{Fu}$ and Williams (2008) also used AFLP technique to estimate genetic diversity within the genus Avena. The authors assessed genetic diversity of 163 genotypes of oat, representing 25 species belonging to the genus Avena of different geographic origin. They obtained 413 polymorphic strands generated by five pairs of AFLP primers. The above-mentioned authors found that species of the same genomes were grouped together on the dendrogram obtained on the basis of polymorphic AFLP markers.

DArT markers were also used to assess genetic similarity in oat. To identify the relationship of 134 oat cultivars from different countries, $\mathrm{T}$ in $\mathrm{k}$ e r et al. (2009) used 1295 DArT polymorphic markers. On the dendrogram obtained using the UPGMA method, the authors distinguished groups of plants which came from the same countries and even from the same breeding programs, as well as groups of spring and winter plants.

\section{SUMMARY}

Using DNA analysis in plant cultivation provided a possibility for fast development of this field of science. Selection by means of DNA markers enables a choice of desirable genotypes at a very early stage of their development, which makes the selection fast and, consequently, considerably shortens the breeding process. As compared to other types of cereals, few DNA markers linked to important functional properties have been identified in oat; similarly, no accurate and dense genetic map of this species has been created. Moreover, evolution of species belonging to the genus Avena has not been completely explained. All that makes oat a very interesting species and because of that it is good material for DNA analysis.

\section{REFERENCES}

Abdellaoui R., Kadri K., Ben Naceur M., Ben Ka ab L.B., 2010. Genetic diversity in some Tunisian barley landraces based on RAPD markers. Pakistan J. Bot. 42 (6): 3775-3782.

Achleitner A., Tinker N.A., Zechner E., Buerst may r H., 2008. Genetic diversity among oat varieties of worldwide origin and associations of AFLP markers with quantitative traits. Theor. Appl. Genet. 117 (7): 1041-1053.

Akkale C., Yildirim Z., Yildirim M.B., Kaya C., Öztürk G., Tanyolaç B., 2010. Assessing genetic diversity of some potato (Solanum tuberosum L.) genotypes grown in Turkey using the AFLP marker technique. Turk. J. Field Crops. 15 (1): 73-78.

Ammiraju J.S.S., Dholakia B.B., Santra D.K., Singh H., Lagu M.D., Tamhankar S.A., Dhaliwal H.S., Ranjekar P.K., 2001. Identification of inter simple sequence repeat (ISSR) markers associated with seed size in wheat. Theor. Appl. Genet. 102 (5): 726-732.

Bao J., Corke H., Sun M., 2006. Analysis of genetic diversity and relationships in waxy rice (Oryza sativa L.) using AFLP and ISSR markers. Genet. Res. Crop Evol. 53 (2): 323-330.

Bednarek P.T., Chwedorzewska K., 2001. Markery molekularne, ich charakterystyka genetyczna oraz wybrane zastosowania w analizie genetycznej roślin. / Molecular markers, their genetic background and some applications in plant genetics. Biotechnologia, 1(52): 9-34. (in Polish)

Botstein D., White R.L., Skolnick M., Davis R.W., 1980. Construction of a genetic linkage map in man using restriction fragment length polymorphisms. Am. J. Hum. Genet. 32:314-331.

Chen,F., Zhang F., Morris C., He Z., Xia X., $\mathrm{Cu}$ i D., 2010. Molecular characterization of the Puroindoline a-D1b allele and development of an STS marker in wheat (Triticum aestivum L.). J. Cereal Sci. 52 (1): 80-82.

Chong J., Reimer E., Somers D., Aung T., Penner G.A., 2004. Development of sequence-characterized amplified region (SCAR) markers for resistance gene $P c 94$ to crown rust in oat . Can. J. Plant Pathol. 26: 89-96.

Chrząstek M., Paczos-Grzęda E., Miazga D., 2004. Charakterystyka cytologiczna i molekularna nie- 
których gatunków z rodzaju Avena. / Cytological and molecular analysis of some species of the genus Avena. Genetyka w ulepszaniu roślin użytkowych. Red. Krajewski P., Zwierzykowski Z., Kachlicki P. IGR, PAN, Poznań: 67-74. (in Polish)

Cole C.G., Goodfellow P.N., Bobrow M., Bentley D.R., 1991. Generation of novel sequence tagged sites (STSs) from discrete chromosomal regions using Alu-PCR. Genomics, 10: 816-826.

de Souza, V.Q., Pereira, A.da S., Kopp, M.M., Coimbra, J.L.M., de Carvalho, F.I.F., da Luz, V.K., de Oliveira, A.C., 2005. Genetic dissimilarity in oat (Avena sativa $\mathrm{L}$.) tolerant and sensitive mutants to organic acids. Bragantia, 64: 569575.

Devos K.M., Atkinson M.D., Chinoy C.N., Francis H.A., Harcurt R.L., Koebner R.M.D., Liu C.J., Masojć P., Xie D.X., Gale M.D., 1993. Chromosomal rearrangements in the rye genom relative to that of wheat. Theor. Appl. Genet. 85: 673-680.

Devos K.M., Gale M.D., 1992. The use of random amplified polymorphic DNA markers in wheat. Theor. Appl. Genet. 84: 573-578.

Drossou A., Katsiotis A., Leggett J.M., Loukas M., Tsakas S., 2004. Genome and species relationships in genus Avena based on RAPD and AFLP molecular markers. Theor. Appl. Genet. 109: 48-54.

Fennimore S.A., Nyquist W.E., Shaner G.E., Doerge R.W., Foley M.E., 1999. Agenetic model and molecular markers for wild oat (Avena fatua $\mathrm{L}$.) seed dormancy. Theor. Appl. Genet. 99: 711-718.

Fernandez M.E., Figueiras A.M., Benito C., 2002. The use of ISSR and RAPD markers for detecting DNA polymorphism, genotype identification and genetic diversity among barley cultivars with known origin. Theor. Appl. Genet. 104: 845-851.

$\mathrm{Fu} \mathrm{Y-B.,} \mathrm{Williams} \mathrm{D.J.,} \mathrm{2008.} \mathrm{AFLP} \mathrm{variation} \mathrm{in}$ 25 Avena species. Theor. Appl. Genet. 117:333-342.

Goffreda J.C., Barnquist W.B., Beer S.C., Tanksley S.D., Sorrels M.E., 1992. Application of molecular markers to assess genetic relationships among accessions of wild oat Avena sierilis. Theor. Appl. Genet. 85:146-151.

Gonzalez J.M., Ferrer E., 1993. Random amplified polymorphic DNA analysis in Hordeum species. Genome, 36:1029-1031.

Goryunova S.V., Chikida N.N., Kochieva E.Z., 2010. RAPD analysis of the intraspecific and interspecific variation and phylogenetic relationships of Aegilops L. species with the U genome. Russ. J. Genet. 46 (7): 841-854.

Gupta P.K., Langridge P., Mir R.R., 2010. Marker-assisted wheat breeding: present status and future possibilities. Mol. Breeding, 26: 145-161.

Haley S.D., Miklas P.N., Stavley J.R., Byrum L., Kelil LD., 1993. Identification of RAPD markers linked to a major rust resistance gene block in common bean. Threor. Appl. Genet. 86: 505-512.

Harada T., Matsukawa K., Sato T., Ishikawa R., Nizeki M., Saito K., 1993. DNA-RAPDs detect genetic variation and paternity in Malus. Euphytica, 65: 87-91.

Helentiaris T., King G., Slocum M., Sidestrang C., Wegman S., 1985. Restriction fragment polymorphisms as probes for plant diversity and their development as tools for applied breeding. Plant Mol. Biol. 5:109-118.

Heun M., Kennedy A.E., Anderson J.A., Lapitan N.L.V., Sorrells M.E., Tanksley S.D., 1991. Construction of a restriction fragment lenght polymorphism map for barley (Hordeum vulgare). Genome, 34: 437-447.

$\mathrm{Hu}$ L, Quiros C.F., 1991. Identification of broccoli and cauliflower cultivars with RAPD markers. Plonl Cell Rep. 10:505-511.

Jaccoud D., Peng K., Feinstein D., Kilian A., 2001. Diversity Arrays: a solid state technology for sequence information independent genotyping. Nucl. Acid. Res. 29:e25.

Jin. H., Domier L.L., Shen X., Kolb F.L., 2000. Combined AFLP and RFLP mapping in two hexaploid oat recombinant inbred populations. Genome, 43: 94-101.

Khlestkina E.K., Pestsova E.G., Salina E., Röder M.S., Arbuzova V.S., Koval S.F., Börner A., 2002. Genetic mapping and tagging of wheat genes using RAPD, STS and SSR markers. Cell. Mol. Biol. Lett. 7 (2 B):795-802.

Kilian A., Huttnere., Wenzl P., Jaccoud D., Carling J., Caig V., Evers M., Heller-Uszynska K., Uszynskig., Caylac., Patarapuwadols., Xia L.,Yang S., Thomson B., 2005. The fast and the cheap: SNP and DArT-based whole genome profiling for crop improvement. Tuberosa R., Philips R.L., Gale M. (red.). proceedings of the International Congress "In the wake of the double helix: from the green revolution to the gene revolution". 27-31 V 2003, Bologna, Italy. Avenue Media: 443-461.

Li C.D., Rossnagel B.G., Scoles G.J., 2000. The development of oat microsatellite markers and their use in identifying relationships among Avena species and oat cultivars. Theor. Appl. Genet. 101: 1259-1268.

Li Y., Niu Y.C., Chen X.M., 2009. Mapping a strip rust resistance gene $\mathrm{YrC591}$ in wheat variety C591 with SSR and AFLP markers. Theor. Appl. Genet. 118: 339346.

Li Z.T., Dhekney S.A., Gray D.J., 2010. Molecular characterization of a SCAR marker purportedly linked to seedlessness in grapevine (Vitis). Mol. Breed. 25 (4): 637-644.

Loarce Y., Sanz M.J., Irigoyen M.L., Fominay a A., Ferrer E., 2009. Mapping of STS markers obtained from oat resistance gene analog sequences. Genome, 52 (7): 608-619. 
Marilla E.F., Scoles G.J., 1996. The use RAPD markers in Hordeum phylogeny. Genome, 39: 646-654.

Mccartney, C.A., Stonehouse, R.G., Rossnagel, B.G., Eckstein, P.E., Scoles, G.J., Zatorski, T., Beattie, A.D., Chong, J., 2011. Mapping of the oat crown rust resistance gene Pc91. Theor. Appl. Genet. 122 (2):317-325.

Messmer M.M., Keller M., Zanetti S., Keller B., 1999. Genetic linkage map of a wheat's spelt cross. Theor. Appl. Genet. 98: 1163-1170.

Michelmore R.W., Paran I., Kesseli R.V., 1991. Identification of markers linked to disease-resistance genes by bulked segregant analysis: A rapid method to detect markers in specific genomic regions by using segregating populations. Proc. Natl. Acad. Sci. USA. 88: 9828-9832.

Milach S.C.K., Rines H.W., Philips R.L., 1997. Molecular genetic mapping of dwarfing genes in oat. Theor. Appl. Genet. 95: 783-790.

Moriya S., Iwanami H., Okada K., Yamamoto T., Abe K., 2011. A practical method for apple cultivar identification and parent-offspring analysis using simple sequence repeat markers. Euphytica, 177 (1): 135-150.

Mullis K.B., 1990. The unusual origin of the polymerase chain reaction. Sci. Am. 262 (4): 56-65

Nair S., Kumar A., Srivastava M.N., Mohan M., 1996. PCR- based DNA majors linked to a gall midge resistance gene $\mathrm{Gm} 4 \mathrm{t}$ has potential for marker-aided selection in rice. Theor. Appl. Genet. 92: 660-665.

O'Donoughue L.S., Kianian S.F., Rayapati P.J., Penner G.A., Sorrells M.E., Tanksley S.D., Phillips R.L., Rines H.W., Lee M., Fedak G., Molnar S.J., Hoffman D., Salas C.A., Wu B., Autrique E., Van Deynze A., 1995. A molecular linkage map of cultivated oat. Genome, 38: 368-380.

Orr W., Molnar S.J., 2008. Development of PCR-based SCAR and CAPS markers linked to $\beta$-glucan and protein content QTL regions in oat. Genome, 51: 421-425.

Paczos-Grzęda E., 2007a. Wykorzystanie metod ISSR i RAPD oraz analizy rodowodów do oceny podobieństwa międzyodmianowego Avena sativa L. / Estimation of similarity of Avena sativa L. cultivars based on RAPD and ISSR methods and pedigree analysis. Zesz. Probl. Post. Nauk Rol. 517: 547-558. (in Polish)

Paczos-Grzęda E., Chrząstek M., Wacko S., Miazga D., 2007b. Ocena podobieństwa genetycznego wybranych form Avena sterilis L. pochodzących z Izraela, Syrii i Libanu. / Assessment of genetic similarity of Avena sterilis 1. Accessions originating from Israel, Syria and Lebanon. Zesz. Probl. Post. Nauk Rol. 517: 559-567. (in Polish)

Paczos-Grzęda E., Kruk K., Okoń S., 2009. Ocena wewnątrzgatunkowego podobieństwa genetycznego Avena fatua $\mathrm{L}$. w oparciu o polimorfizm DNA. /Assessment of intraspecific genetic similarity of Avena fatua $\mathrm{L}$. based on DNA polymorphism. Biul.IHAR, 252: 235-243. (in Polish)
Paczos-Grzęda E., Tyrka M., Wacko S., Miazga D., 2007c. Wykorzystanie markerów SSR do oceny podobieństwa genetycznego heksaploidalnych gatunków z rodzaju Avena L. / Application of SSR markers for genetic similarity assessment of hexaploid species of the genus Avena L. Zesz. Probl. Post. Nauk Rol. 517: 577-584. (in Polish)

Paran I., Michelmore R.W., 1993. Development of reliable PCR-based markers linked to downy mildew resistance genes in lettuce. Theor. Appl. Genet. 85: 985-993.

Penner G.A., Chong J., Levesque-Lemay M., Molnar S.J., Fedak G., 1993. Identification of RAPD marker linked to the oat stem rust gene $\mathrm{Pg} 3$. Theor. Appl. Genet. 85: 702-705.

Portyanko V.A., Hoffman D., Lee M., Holland J.B., 2001. A linkage map of hexaploid oat based on grass anchor and its relationship to other oat maps. Genome, 44: 249-265.

Pradeep Redy M., Salara N., Siddiq E.A., 2002. Inter simple sequence repeat (ISSR) polymorphism and its application in plant breeding. Euphytica, 128: 9-17.

Qian W., Ge S., Hong D-Y., 2001. Genetic variation within and among populations of a wild rice Oryza granulata from China detected by RAPD and ISSR markers. Theor. Appl. Genet. 102: 440-449.

Ramsay L., Macaulay M., Degli-Ivanissevich S., Maclean K., Cardle L., Fuller J., Edwards K.J., Tuvesson S., Morgante M., Massari A., 2000. A simple sequence repeat-based linkage map of barley. Genetics, 156: 1997-2005.

Sharma S.K., Knox M.R., Ellis T.H.N., 1996. AFLP analysis of the diversity and phylogeny of Lens and its comparison with RAPD analysis. Theor. Appl. Genet. 93: 751-758.

Sztuba-Solińska J ., 2005. Systemy markerów molekularnych i ich zastosowanie w hodowli roślin. / Molecular marker systems and their application in plant breeding. Kosmos, 54[2-3(267-268)]: 227-239. (in Polish)

Tinker, N.A., Kilian, A., Wight, C.P., HellerUszynska, K., Wenzl, P., Rines, H.W., Bjřrnstad, Ĺ., Howarth, C.J., Jannink, J.-L., Anderson, J.M., Rossnagel, B.G., Stuthman, D.D., Sorrells, M.E., Jackson, E.W., Tuvesson, S., Kolb, F.L., Olsson, O., Federizzi, L., Carson, M.L. Ohm, H.W., Molnar, S.J. Scoles, G.J., Eckstein, P.E., Bonman, J.M., Ceplitis, A., Langdon, T., 2009. New DArT markers for oat provide enhanced map coverage and global germplasm characterization. BMC Genomics 10, art. no. 39 .

Uhrin A., Láng L., Bedo Z., 2008. Comparison of PCR-based DNA markers for using different $\operatorname{Lr} 19$ and Lr24 leaf rust resistance wheat sources. Cereal Res. Commun. 36(4): 533-541.

Vos P., Hogers R., Bleeker M., Reijans M., van de Lee T., Hornes M., Frijters A., Plot J., Peleman J., Kupier M., Zebau M., 
1995. AFLP-a new technique for DNA fingerprinting. Nucl. Acids Res.23:4407-4414.

Wang C., Zhang Y., Han D., Kang Z., Li G., Cao A., Chen P., 2008. SSR and STS markers for wheat stripe rust resistance gene $\operatorname{Yr} 26$. Euphytica, 159 (3): $359-366$

Weeden N.F., Wu W.Y., Gu W.K., Cargnoni T.L., Lu J., Timmerman G.M., Wolko B., Zhu Z., 1994. Applications of DNA amplification technology to vegetable breeding. Proc. of the 7th International Congress of SABRAO. Taipei, Taiwan. 37-445.

Weining S., Langridge P., 1991. Identification and mapping of polymorphisms in cereals based on the polymerase chain reaction. Threor. Appl. Genet. 82: 209216.

Welsh J., Honeycutt R.J., MeClelland M., Sorb a l B.W.S., 1991. Parentage determination in maize hybrids using the arbitrarily primed polymerase chain reaction (AP-PC'R). Theor. Appl. Genel. 82: 473-476.

Wight C.P., Tinker N.A., Kianian S.F., Sorrells M.E., O’Donoughue L.S., Hoffman D., Groh S., Scoles G.J., Li C.D., Webster F.H., Philips R.L., Rines H.W., Livingston S.M., Armstrong K.C., Fedak G., Molnar S.J., 2003. A molecular marker map in 'Kanota' ' 'Ogle' hexaploid oat (Avena ssp.) enhanced by additional markers and a robust framework. Genome, 46: 28-47.

Wilke S.E., Is a c P.G. Slater R.J., 1993. Random amplified polymorphic DNA (RAPD) markers for genetic analysis in Allium. Theor. Appl. Genel. 86: 497-504.

Williams J.G.K., Kubelik A.R., Livak K.J., Rafalski J.A, Tingey S.V., 1990. DNA polymorphisms amplified by arbitrary primers are useful as genetic markers. Nucl. Acid. Res. 18: 6531-6535.

Wolko B., Irzykowska L., Święcicki W.K., 1999. AFLP i SSR - systemy markerowe przydatne w hodowli roślin. / AFLP and SSR - marker systems useful in plant breeding. Post. Nauk Rol. 2:59-70.

Wolko B., Kruszka K., 1997. Markery molekularne w badaniach zmienności genetycznej roślin. / Molecular markers in plant genetic variability research. Post. Nauk Rol. 3: 3-20

Yu C., Leišová L., Kučera V., Vyvadilová M., Ovesná J., Dotlačil L., Hu S., 2007. Assessment of genetic diversity of yellow-seeded rapeseed (Brassica napus L.) accessions by AFLP markers. Czech J. Genet. Plant, 43 (3): 105-112.
Yu X., Bai G., Luo N., Chen Z., Liu S., Liu J., Warnke S.E., Jiang Y., 2011. Association of simple sequence repeat (SSR) markers with submergence tolerance in diverse populations of perennial ryegrass. Plant Sci. 180 (2): 391-398.

Zhou X., Jellen E.N., Murphy J.P., 1999. Progenitor germplasm of domesticated hexaploid oat. Crop Sci. 39: 1208-1214.

Zhu J., Gale M.D., Quarrie S., Jackson M.T., Bryan G.J., 1998. AFLP markers for the study of rice diversity. Theor. Appl. Genet. 96: 602-611.

Zietkiewicz E., Rafalski A., Labuda D., 1994. Genome fingerprinting by simple-sequence repeat (SSR)-anchored polymerase chain reaction amplification. Genomics, 20: 176-183.

Zorzatto C., Chiari L., De Araújo Bitencourt G., Do Valle C.B., De Campos Leguizamón G.O., Schuster I., Pagliarini, M.S., 2010. Identification of a molecular marker linked to apomixes in Brachiaria humidicola (Poaceae). Plant Breeding, 129 (6): 734-736.

\section{Charakterystyka technik analiz DNA oraz ich wykorzystanie w badaniach owsa (Avena L.)}

\section{Streszczenie}

Markery DNA znalazły zastosowanie nie tylko w ocenie podobieństwa lub dystansu genetycznego, ale również w selekcji i identyfikacji pożądanych form, ocenie wyrównania materiałów hodowlanych, potwierdzaniu skuteczności krzyżowań, ocenie czystości materiału siewnego czy też do identyfikacji genów, warunkujących ważne cechy użytkowe. U owsa posłużyły one między innymi do konstrukcji i zagęszczenia map genetycznych zarówno gatunków heksaploidalnych jak i diploidalnych. Opracowanie markerów dla niektórych cech użytkowych pozwala na szybką selekcję genotypów zawierających geny karłowatości, odporności na rdzę koronową czy mączniaka prawdziwego. Natomiast prowadzone liczne analizy podobieństwa genetycznego różnych gatunków z rodzaju Avena mogą przyczynić się do wyjaśnienia ewolucji w obrębie tego rodzaju jak również mogą wyjaśnić powstawanie poszczególnych gatunków owsa. 